\title{
Effect of Sources and Graded Levels of Sulphur on Growth and Yield of Bellary Onion (Allium cepa L.)
}

\author{
Bhoite Vivek*, M. R. Backiyavathy and Prajakta Metkari-Kharat \\ Department of Soil Science and Agricultural Chemistry, Tamil Nadu Agricultural University, \\ Coimbatore-3, India \\ *Corresponding author
}

\section{A B S T R A C T}

Keywords

Sulphur, sources, levels, Onion, bulb yield

Article Info

Accepted:

22 August 2019

Available Online:

10 September 2019
A field experiment was conducted to study the effect of different sources and graded levels of sulphur on growth, yield attributes and yield of bellary onion at National Institute for Abiotic Stress Management, Malegaon Khurd, Baramati, Pune, Maharashtra. The treatments comprised of three sources of sulphur (Elemental sulphur- Bentonite clay, Potassium schoenite and ammonium sulphate) with graded levels of sulphur viz., $0,30,45$ and $60 \mathrm{~kg} \mathrm{~S} \mathrm{ha}^{-1}$. The experiment was laid out in randomized block design with four replications. The recommended doses of fertilizers were applied as per the crop production guide. Growth parameters viz., plant height, number of leaves and neck size were recorded at 30,60, 90 and 120 DAT and yield attributing parameters viz., polar diameter, equatorial diameter and bulb yield were recorded at harvest. The results showed that growth attributes viz., plant height, number of leaves, neck size and yield parameters viz., polar diameter, equatorial diameter and average weight of bulb increased significantly up to $45 \mathrm{~kg} \mathrm{~S} \mathrm{ha}^{-1}$ and thereafter, declined in all sources of sulphur. The maximum bulb yield was obtained with the application of $45 \mathrm{~kg} \mathrm{~S} h a^{-1}$ and it was significantly superior to $30 \mathrm{~kg} \mathrm{~S} \mathrm{ha}^{-1}$ and at par with $60 \mathrm{~kg} \mathrm{~S}^{-1}$ in all sources of sulphur. Among the methods of application, $45 \mathrm{~kg} \mathrm{~S}^{-1} \mathrm{ha}^{-1}$ as superior over nutripellet pack as soil application shows superiority over all other treatments.

\section{Introduction}

Onion (Allium cepa L.) belong to the family of Alliaceae. Onion is one of the most important commercial vegetable and spice crop cultivated extensively in India. It is a short duration and quick growing crop and bulb is used as vegetable, spice and for medicinal value. The edible portion of onion is the bulb, which is a modified organ consisting of thickened fleshy scale leaves and stem plate. It is used in several ways as fresh, frozen and dehydrated bulbs. As a nutritious vegetable, it contains carbohydrate $(11.0 \mathrm{~g})$, protein $(1.2 \mathrm{~g})$, calcium $(180 \mathrm{mg})$, phosphorus $(50 \mathrm{mg})$, iron $(0.7 \mathrm{mg})$, nicotinic acid $(0.4 \mathrm{mg})$, riboflavin $(0.01 \mathrm{mg})$ and vitamin $\mathrm{C}(11.0 \mathrm{mg})$ in each 100 $\mathrm{g}$ of edible portion (Bose et al., 2000). Sulphur 
requirement of onion is almost similar to that of phosphorus. Sulphur is a constituent of secondary compounds viz. allin, cycloallin and thiopropanol which are responsible for pungency and medicinal properties of onion and also inducing resistance against pests and diseases.

Sulphur deficiency in plant will affect the nitrogen metabolism in plants. Protein synthesis decreases when nitrogen is not fully utilized resulting in accumulation of non protein nitrogen in the plant. The critical N: S ratio varied with the crop and there is a strong relationship between total nitrogen, total sulphur and N-protein sulphur ratio. Sulphur deficiency causes 10 to 34 percent yield reduction in commercial crops. Sulphur deficiency is widespread in Indian soils and more than $40 \%$ of the Indian soils are found to be deficient in sulphur (Tandon and Messick, 2007). Sulphur deficient plants had poor utilization of nitrogen, phosphorus and potash and showed a significant reduction in catalase activities at all stage of crop growth. Sulphur deficiency during bulb development had detrimental effect on yield and quality of onion.

Sulphur fertilization is required for alleviating sulphur deficiency and for increased crop productivity in crops like onion. In recent years, sulphur is applied as soil amendment and also as a factor of increasing fertilizer use efficiency. Application of sulphur has several beneficial effects such as reducing $\mathrm{pH}$, improving soil water retention and increasing availability of nutrients. Gondane et al., (2018) reported that a total soluble solids of onion bulb was significantly influenced due to application of different levels of sulphur. In the past, sulphur need of soil and crop was satisfied by use of seemingly incidental means like use of sulphur bearing superphosphate, ammonium sulphate, potassium sulphate, sulphur based pesticides, atmospheric $\mathrm{SO}_{2}$ and manures etc. But in recent years, the trend to use high analysis fertilizers and pesticides which are sulphur free, has resulted in sulphur deficient soils. It is necessary to estimate onion response to sulphur fertilization on sulphur deficient soils of Maharashtra. It is also necessary to identify the cheaper and easily available source of sulphur fertilizer. It was strongly felt that enriching the soil with sulphur fertilizer would be beneficial for onion crop of Western Maharashtra region. An investigation was, therefore, conducted to study the effect of sources and levels of sulphur on growth, productivity of onion.

\section{Materials and Methods}

A field experiment was conducted during Rabi, 2018 and 2019 at National Institute for Abiotic Stress Management (ICAR-NIASM), Malegaon Khurd, Baramati, Pune, Maharashtra. The experimental soil was alkaline ( $\mathrm{pH} 8.2$ ), clay loam in texture, low in organic carbon $\left(3.2 \mathrm{~g} \mathrm{~kg}^{-1}\right)$, low in $\mathrm{KMnO}_{4}$ (110 kg ha $\left.{ }^{-1}\right)$, high in Olsen P $\left(15 \mathrm{~kg} \mathrm{ha}^{-1}\right)$ and medium in $\mathrm{NH}_{4} \mathrm{OAC} \mathrm{K}\left(200 \mathrm{~kg} \mathrm{ha}^{-1}\right)$. The soil had $\mathrm{Ca}$ content of $611 \mathrm{ppm}, \mathrm{Mg}$ content of 53 ppm and $\mathrm{S}$ content of $6.3 \mathrm{ppm}$. The experiment was laid out in randomized block design with three replications. There were fourteen treatments comprising of four doses of sulphur viz., 0, 30, 45 and $60 \mathrm{~kg} \mathrm{ha}^{-1}$ and three sulphur sources (Elemental sulphurBentonite clay, Potassium schoenite and ammonium sulphate). Plot size was $3 \times 4 \mathrm{~m}$ and plant spacing was $15 \times 10 \mathrm{~cm}$. Recommended dose of $\mathrm{N}: \mathrm{P}_{2} \mathrm{O}_{5}: \mathrm{K}_{2} \mathrm{O}$ (110:40:60 kg ha ${ }^{-1}$ ) was applied to all the plots except control. The sources of nitrogen, phosphorus and potassium were urea, dia ammonium phosphate and muriate of potash respectively. The sources of sulphur were elemental sulphur (80\% sulphur as Bentonite Clay), potassium schoenite (21.5\% sulphur) and ammonium sulphate (24\% sulphur). 100 $\%$ RD of phosphorus and potassium and $50 \%$ RD of nitrogen were applied before transplanting. The remaining $50 \% \mathrm{RD}$ of 
nitrogen was applied in two equal splits at 30 and 45 days after transplanting. Onion variety Bhima Kiran was selected for the study. Regular package of package of practices were followed as per crop production guide. The observations were recorded from five randomly selected competitive plants in each treatment and replication. Growth parameters viz., plant height, number of leaves, neck size, polar and equatorial diameter of bulb and average bulb weight were recorded. Bulb yield per hectare was computed from the yield obtained per plot. The results on growth, yield attributing parameters and yield were tabulated and subjected to statistical analysis. The total variation of different treatments was tested for significance by " $F$ " test using analysis of variance technique.

\section{Results and Discussion}

\section{Growth parameters}

There was a considerable increase in plant height of onion in all the treatments from 30 to 120 days of crop growth. Maximum plant height of $72 \mathrm{~cm}$ was registered in the treatment $\mathrm{T}_{9}$ receiving $45 \mathrm{~kg} \quad \mathrm{~S} \quad \mathrm{ha}^{-1}$ as potassium schoenite through nutripellet pack which was also significantly superior over rest of the treatments. Plant height was minimum $(33 \mathrm{~cm})$ in control treatment without any NPK and sulphur fertilization (Table1). Sulphur application along with recommended dose of NPK fertilizers and organic manure exerted positive effect on plant height which might be due to the role of nitrogen in chlorophyll structure which is responsible for photosynthesis and manufacture of food material in the plants. Irrespective of the treatments, the numbers of leaves of onion were increased from 30 to 120 days after transplanting. Maximum number of leaves of 8.1, 9.7, 11.7 and 11.7 were noticed in the treatment $\mathrm{T}_{9}$ on $30,60,90$ and 120 DAT, respectively. This treatment was significantly superior over rest of the treatments, on all the days of observations, which revealed superiority of potassium schoenite applied @ $45 \mathrm{~kg} \mathrm{~S} \mathrm{ha}{ }^{-1}$ through nutripellet pack to other sources of sulphur and other methods of application. Nayak et al., (2016) reported that the yield attributes like plant height, bulb length, bulb diameter, neck length and average weight of bulb were increased significantly up to $35 \mathrm{~kg}$ sulphur ha ${ }^{-1}$ and thereafter, declined with higher dose of sulphur application $(50 \mathrm{~kg}$ $\mathrm{S} \mathrm{ha}^{-1}$ ) in both the sources.

\section{Yield attributing parameters}

Application of sulphur through different sources to onion crop significantly increased polar diameter of onion over control treatment. Maximum polar diameter of 5.98 $\mathrm{cm}$ was noticed in the treatments $\mathrm{T}_{9}$ receiving $45 \mathrm{~kg} \mathrm{~S} \mathrm{ha}^{-1}$ as potassium schoenite through nutripellet pack which was significantly superior over all other treatments (Table 2). Tripathy et al.,(2013) reported that maximum equatorial $(5.17 \mathrm{~cm})$ and polar $(5.17 \mathrm{~cm})$ diameter of bulb recorded with the application of $30 \mathrm{~kg} \mathrm{~S} \mathrm{ha}^{-1}$. Maximum equatorial diameter of $8.55 \mathrm{~cm}$ was noticed in the treatment $\mathrm{T} 9$ receiving $45 \mathrm{~kg} \mathrm{~S} \mathrm{ha}^{-1}$ as potassium schoenite through nutripellet pack which is significantly superior over a treatment $T_{5}$ receiving $45 \mathrm{~kg} \mathrm{~S}$ $\mathrm{ha}^{-1}$ as elemental sulphur with Thiobacillus and nutripellet pack application $(7.43 \mathrm{~cm})$, which showed the significance of potassium schoenite over elemental source of sulphur in respect of equatorial diameter (Table2). Chattopadhyay et al., (2015) reported that maximum equatorial $(5.81 \mathrm{~cm})$ and polar diameter $(6.32 \mathrm{~cm})$ of bulbs were found in treatment where plants received elemental sulphur at $30 \mathrm{~kg} \mathrm{ha}^{-1}$. Thus both polar and equatorial diameter play important role in determining the shape and size of onion bulbs.

More efficient sulphur utilization resulted in greater increase in bulb diameter. Neck size of onion plant was significantly improved due to application of $45 \mathrm{~kg} \mathrm{~S} \mathrm{ha}{ }^{-1}$ as potassium 
schoenite through nutripellet peck $\left(\mathrm{T}_{9}\right)$ and 45 $\mathrm{kg} \mathrm{S} \mathrm{ha}{ }^{-1}$ as elemental sulphur + Thiobacillus through nutripellet pack $\left(\mathrm{T}_{5}\right)$ over all other treatments.

Maximum neck size $(2.29 \mathrm{~cm})$ was noticed in the treatment $\mathrm{T}_{9}$ followed by the treatment $\mathrm{T}_{5}$. Ulkey et al., (2015) reported that application of $30 \mathrm{~kg} \mathrm{~S} \mathrm{ha}^{-1}$ resulted neck thickness 1.34 $\mathrm{cm}$ of onion.

\section{Yield}

Maximum bulb yield of $46.55 \mathrm{~kg}$ plot $^{-1}$ was recorded in the treatment $\mathrm{T}_{9}$ followed by a treatment $\mathrm{T}_{5}\left(40.14 \mathrm{~kg}\right.$ plot $\left.^{-1}\right)$. There was significance elevation in the bulb yield of onion owing to sulphur application through different sources over a control treatment. Qureshi and Lawande (2006) reported that onion yield increased with increasing sulphur nutrition levels up to $75 \mathrm{~kg} \mathrm{~S} \mathrm{ha}^{-1}$ yield in low sulphur soils $(<10 \mathrm{ppm} \mathrm{S})$.

Meher et al., (2016) reported that graded levels of sulphur application linearly increased the yield up to $50 \mathrm{~kg} \mathrm{ha}^{-1}$ with bulb yield of 35.5 tonnes. The marketable bulb yield obtained in the treatment $\mathrm{T}_{9}$ and $\mathrm{T}_{5}$ were significantly higher over rest of the treatments (Table2). Gondane et al.,(2018) revealed that the sulphur application @ $40 \mathrm{~kg} \mathrm{ha}^{-1}$ was found to be better in yield contributing characters like weight of fresh as well as cured bulb, diameter of bulb, number of marketable bulbs, weight of marketable bulb per plot, total yield per plot and total yield per hectare.

Potassium schoenite and elemental sulphur applied@45kg S ha ${ }^{-1}$ thorough nutripellet pack have assisted in elevating the marketable yield as compared to a dose of $60 \mathrm{~kg} \mathrm{~S} \mathrm{ha}^{-1}$. Mishu et al., (2013) reported that application of $40 \mathrm{~kg} \mathrm{~S} \mathrm{ha}^{-1}$ resulted in the highest yield (10.65 $\mathrm{t} \mathrm{ha}^{-1}$ ) among the different doses of sulphur. There was positive effect of sulphur application on both bulb yields per plot and per hectare. Increasing dose of sulphur from 30 to $45 \mathrm{~kg} \mathrm{ha}^{-1}$ also caused significant increase in the yield of onion.

Maximum yield production was noticed the treatment receiving $45 \mathrm{~kg}$ sulphur ha ${ }^{-1}$ through potassium schoenite followed by elemental sulphur, therefore, depicting superiority of potassium schoenite over other two sources of sulphur.

Application of 45 and be $60 \mathrm{~kg} \mathrm{~S} \mathrm{ha}^{-1}$ through potassium schoenite, elemental sulphur and ammonium sulphate significantly increased the bulb yield over the treatment receiving 30 $\mathrm{kg} S$ through elemental sulphur alone (T2). Sulphur dose of $45 \mathrm{~kg} \mathrm{~S} \mathrm{ha}^{-1}$ is sufficient for Bhima Kiran variety of onion grown in medium black soils of Baramati area.

The results can be summarized that application of $45 \mathrm{~kg}$ sulphur ha ${ }^{-1}$ is sufficient for Bhima Kiran variety of bellary onion grown in medium black soils of Baramati area.

Application of potassium schoenite applied @ $45 \mathrm{~kg} \mathrm{~S} \mathrm{ha}^{-1}$ through nutripellet pack to other sources of sulphur and its other method of application shows better results in number of leaves in onion. Neck size of onion plant was significantly improved due to application of $45 \mathrm{~kg}$ sulphur $\mathrm{ha}^{-1}$ as potassium schoenite through nutripellet pack and $45 \mathrm{~kg}$ sulphur ha as elemental sulphur + thiobacillus through nutripellet pack over all other treatments.

Soil application of nutrients is inferior to nutripellet pack application as far as neck size is concerned. Application of sulphur @ 45 and $60 \mathrm{~kg}$ sulphur $\mathrm{ha}^{-1}$ resulted in significantly increase in equatorial diameter of onion, over a treatment $30 \mathrm{~kg}$ sulphur $\mathrm{ha}^{-1}$ by surface application. 
Table.1 Effect of sources and graded levels of sulphur on growth attributes attributes of bellary onion

\begin{tabular}{|c|c|c|c|c|c|c|c|c|c|}
\hline \multirow[t]{2}{*}{ Treatments } & \multicolumn{4}{|c|}{$\begin{array}{l}\text { Plant height } \\
\text { (cm) }\end{array}$} & \multicolumn{4}{|c|}{ No. of leaves } & \multirow{2}{*}{$\begin{array}{c}\begin{array}{c}\text { Neck } \\
\text { size } \\
(\mathbf{c m})\end{array} \\
\begin{array}{c}\text { At } \\
\text { harvest }\end{array}\end{array}$} \\
\hline & $\begin{array}{c}\text { 30 } \\
\text { DAT }\end{array}$ & $\begin{array}{c}60 \\
\text { DAT }\end{array}$ & $\begin{array}{c}90 \\
\text { DAT }\end{array}$ & $\begin{array}{l}\text { 120 } \\
\text { DAT }\end{array}$ & $\begin{array}{c}\text { 30 } \\
\text { DAT }\end{array}$ & $\begin{array}{c}\text { 60 } \\
\text { DAT }\end{array}$ & $\begin{array}{c}90 \\
\text { DAT }\end{array}$ & $\begin{array}{l}120 \\
\text { DAT }\end{array}$ & \\
\hline $\mathbf{T}_{1}$ Absolute Control & 23 & 24 & 26 & 33 & 5.1 & 6.1 & 7.0 & 7.0 & 1.13 \\
\hline $\begin{array}{l}\mathrm{T}_{2} \mathrm{RDF}+\mathrm{S} @ 30 \mathrm{~kg} \mathrm{ha}^{-1} \text { soil } \\
\text { application }\end{array}$ & 37 & 42 & 52 & 54 & 6.5 & 7.1 & 7.6 & 7.6 & 1.26 \\
\hline $\begin{array}{l}\mathrm{T}_{3} \mathrm{RDF}+\mathrm{S} @ 45 \mathrm{~kg} \mathrm{ha}^{-1} \text { as elemental } \\
\text { S+Thiobacillus -Soil application }\end{array}$ & 35 & 41 & 54 & 56 & 6.6 & 8.1 & 9.3 & 9.4 & 1.43 \\
\hline $\begin{array}{l}\mathrm{T}_{4} \mathrm{RDF}+\mathrm{S} @ 60 \mathrm{~kg} \mathrm{ha}^{-1} \text { as elemental } \\
\text { S+Thiobacillus - Soil application }\end{array}$ & 40 & 42 & 43 & 46 & 7.1 & 7.1 & 7.3 & 7.3 & 1.06 \\
\hline $\begin{array}{l}\mathrm{T}_{5} \mathrm{RDF}+\mathrm{S} @ 45 \mathrm{~kg} \mathrm{ha}^{-1} \text { as elemental } \\
\mathrm{S}+\text { Thiobacillus -Nutripellet Pack }\end{array}$ & 41 & 46 & 58 & 59 & 6.2 & 7.2 & 9.6 & 9.6 & 1.86 \\
\hline $\begin{array}{l}\mathrm{T}_{6} \mathrm{RDF}+\mathrm{S} @ 60 \mathrm{~kg} \mathrm{ha}^{-1} \text { as elemental } \\
\text { S+Thiobacillus -Nutripellet Pack }\end{array}$ & 30 & 38 & 49 & 51 & 5.7 & 6.1 & 8.0 & 8.0 & 1.66 \\
\hline $\begin{array}{l}\mathrm{T}_{7} \mathrm{RDF}+\mathrm{S} @ 45 \mathrm{~kg} \mathrm{ha}^{-1} \text { as Potassium } \\
\text { Schoenite-Soil application }\end{array}$ & 43 & 45 & 48 & 51 & 6.0 & 6.6 & 7.3 & 7.5 & 1.36 \\
\hline $\begin{array}{l}T_{8} \text { RDF +S@60 } \mathrm{kg} \mathrm{ha}^{-1} \text { as Potassium } \\
\text { Schoenite-Soil application }\end{array}$ & 32 & 41 & 49 & 51 & 5.9 & 6.4 & 7.3 & 7.4 & 1.56 \\
\hline $\begin{array}{l}\mathrm{T}_{9} \mathrm{RDF}+\mathrm{S} @ 45 \mathrm{~kg} \mathrm{ha}^{-1} \text { as Potassium } \\
\text { Schoenite - Nutripellet Pack }\end{array}$ & 50 & 59 & 72 & 72 & 8.10 & 9.7 & 11.7 & 11.7 & 2.29 \\
\hline 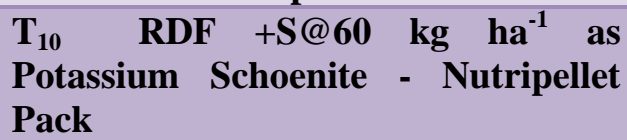 & 32 & 41 & 49 & 50 & 6.1 & 7.6 & 8.6 & 8.6 & 1.66 \\
\hline $\begin{array}{lcrr}\mathrm{T}_{11} \quad \mathrm{RDF} & +\mathrm{S} @ 45 \quad \mathrm{~kg} & \mathrm{ha}^{-1} \text { as } \\
\text { Ammonium } & \text { Sulphate } & & \text {-Soil } \\
\text { application } & & & \end{array}$ & 39 & 50 & 52 & 52 & 6.9 & 7.1 & 8.6 & 8.7 & 1.53 \\
\hline $\begin{array}{lrrr}\mathrm{T}_{12} \quad \mathrm{RDF} & +\mathrm{S} @ 60 \quad \mathrm{~kg} & \mathrm{ha}^{-1} \text { as } \\
\text { Ammonium } \\
\text { application }\end{array}$ & 39 & 47 & 56 & 56 & 6.4 & 7.5 & 8.7 & 8.8 & 1.33 \\
\hline $\begin{array}{l}\mathrm{T}_{13} \text { RDF } \\
\text { Ammonium Sulphate } \\
\text { Pack }\end{array}$ & 30 & 45 & 56 & 56 & 5.7 & 7.2 & 9.0 & 9.0 & 1.53 \\
\hline 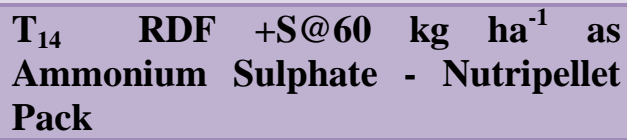 & 32 & 45 & 55 & 56 & 5.7 & 6.9 & 7.6 & 7.7 & 1.56 \\
\hline SED & 2.1 & 0.16 & 5.0 & 0.40 & 0.22 & 0.04 & 0.84 & 0.03 & 0.17 \\
\hline $\mathrm{CD}(\mathrm{p}=0.05)$ & 4.3 & 0.38 & 10.3 & 0.96 & 0.46 & 0.09 & 1.73 & 0.08 & 0.36 \\
\hline
\end{tabular}

RDF: Recommended dose of NPK fertilizers 
Table.2 Effect of sources and graded levels of sulphur on Yield attributes and yield component of bellary onion

\begin{tabular}{|c|c|c|c|c|c|}
\hline Treatments & $\begin{array}{l}\text { Polar } \\
\text { diameter } \\
(\mathrm{cm})\end{array}$ & $\begin{array}{l}\text { Equatorial } \\
\text { diameter } \\
(\mathrm{cm})\end{array}$ & $\begin{array}{l}\text { Bulb } \\
\text { yield } \\
\text { kg plot }^{-1}\end{array}$ & $\begin{array}{l}\text { Yield } \\
\text { t hat }\end{array}$ & $\begin{array}{l}\text { Marketable } \\
\text { yield t ha }\end{array}$ \\
\hline $\mathbf{T}_{1}$ Absolute Control & 3.25 & 4.46 & 23.67 & 29.5 & 26.85 \\
\hline $\mathrm{T}_{2} \mathrm{RDF}+\mathrm{S} @ 30 \mathrm{~kg} \mathrm{ha}^{-1}$ soil application & 4.26 & 5.43 & 29.75 & 37.2 & 34.86 \\
\hline $\begin{array}{l}\mathrm{T}_{3} \mathrm{RDF}+\mathrm{S} @ 45 \mathrm{~kg} \mathrm{ha}^{-1} \text { as elemental S+ } \\
\text { Thiobacillus } \text {-Soil application }\end{array}$ & 4.23 & 5.70 & 34.83 & 43.5 & 41.51 \\
\hline $\begin{array}{l}\mathrm{T}_{4} \mathrm{RDF}+\mathrm{S} @ 60 \mathrm{~kg} \mathrm{ha}^{-1} \text { as elemental S+ } \\
\text { Thiobacillus - Soil application }\end{array}$ & 4.6 & 6.66 & 34.22 & 42.8 & 41.63 \\
\hline $\begin{array}{l}\mathrm{T}_{5} \mathrm{RDF}+\mathrm{S} @ 45 \mathrm{~kg} \mathrm{ha}^{-1} \text { as elemental } \mathrm{S}+ \\
\text { Thiobacillus -Nutripellet Pack }\end{array}$ & 5.35 & 7.43 & 40.14 & 48.7 & 46.88 \\
\hline $\begin{array}{l}\mathrm{T}_{6} \mathrm{RDF}+\mathrm{S} @ 60 \mathrm{~kg} \mathrm{ha}^{-1} \text { as elemental S + } \\
\text { Thiobacillus -Nutripellet Pack }\end{array}$ & 5.01 & 6.56 & 32.96 & 41.2 & 38.94 \\
\hline $\begin{array}{l}\mathrm{T}_{7} \mathrm{RDF}+\mathrm{S} @ 45 \mathrm{~kg} \mathrm{ha}^{-1} \text { as Potassium } \\
\text { Schoenite-Soil application }\end{array}$ & 4.87 & 6.43 & 34.65 & 42.9 & 39.55 \\
\hline $\begin{array}{l}\mathrm{T}_{8} \mathrm{RDF}+\mathrm{S} @ \underset{60}{\mathrm{~kg}} \mathrm{ha}^{-1} \text { as Potassium } \\
\text { Schoenite-Soil application }\end{array}$ & 4.67 & 6.36 & 34.41 & 43.0 & 41.99 \\
\hline $\begin{array}{l}\text { T9 RDF +S @ } 45 \mathrm{~kg} \mathrm{ha}^{-1} \text { as Potassium } \\
\text { Schoenite - Nutripellet Pack }\end{array}$ & 5.98 & 8.53 & 46.55 & 53.9 & 52.87 \\
\hline $\begin{array}{l}\mathrm{T}_{10} \mathrm{RDF}+\mathrm{S} @ 60 \mathrm{~kg} \mathrm{ha} \mathrm{h}^{-1} \text { as Potassium } \\
\text { Schoenite - Nutripellet Pack }\end{array}$ & 5.02 & 7.00 & 33.35 & 41.5 & 39.59 \\
\hline $\begin{array}{l}\mathrm{T}_{11} \mathrm{RDF}+\mathrm{S} @ 45 \mathrm{~kg} \mathrm{ha}^{-1} \text { as Ammonium } \\
\text { Sulphate -Soil application }\end{array}$ & 5.00 & 6.63 & 35.02 & 44.8 & 42.05 \\
\hline $\begin{array}{l}\mathrm{T}_{12} \mathrm{RDF}+\mathrm{S} @ 60 \mathrm{~kg} \mathrm{ha}^{-1} \text { as Ammonium } \\
\text { Sulphate -Soil application }\end{array}$ & 5.04 & 7.06 & 35.0 & 44.6 & 41.77 \\
\hline $\begin{array}{l}\mathrm{T}_{13} \mathrm{RDF}+\mathrm{S} @ 45 \mathrm{~kg} \mathrm{ha}^{-1} \text { as Ammonium } \\
\text { Sulphate - Nutripellet Pack }\end{array}$ & 5.15 & 7.01 & 33.18 & 41.5 & 40.82 \\
\hline $\begin{array}{l}\mathrm{T}_{14} \mathrm{RDF}+\mathrm{S} @ 60 \mathrm{~kg} \mathrm{ha}^{-1} \text { as Ammonium } \\
\text { Sulphate - Nutripellet Pack }\end{array}$ & 4.82 & 7.00 & 35.32 & 44.4 & 42.42 \\
\hline SED & 0.16 & 0.13 & 1.05 & 0.98 & 1.17 \\
\hline $\mathrm{CD}(\mathrm{P}=0.05)$ & 0.33 & 0.27 & 2.13 & 1.72 & 2.24 \\
\hline
\end{tabular}

\section{References}

Panse, V.G. and Sukhatme, P.V. 1989. Statistical Methods for Agricultural Workers. Indian Council of Agricultural Research, New Delhi.

Randle, W. M. and Bussard, M. L.1993. Pungency and sugars of short day onion as affected by sulphur nutrition. J. Amer. Soc. Hort. Sci. 118: 766-70.
Qureshi A. A., and Lawande K. E.,2006.Response of onion (Allium сера) to sulphur application for yield, quality and its storability in Sdeficient soils. Indian Journal of Agricultural Sciences.76 (9):535-7.

Mishu Hassan Mahmud, hmed Fahim, Rafil M.Y., Golam Faruq and Latif M.A., 2013. Effect of sulphur on growth, yield and yield attributes in onion 
(Allium cepa). Australian Journal of Crop Science 7(9):1416-1422

Tripathy P., Sahoo B.B., Priyadarshini A., Das

S. K. and Dash D.K., 2013.Effect of sources and levels of sulphur on growth, yield and bulb quality in onion Allium cepa L.) International Journal of Bioresource and Stress Management, 4(4):641-644.

Chattopadhyay S., Santra P., Behera S. and Maity T.K., 2015.Efficacy of sulphur on growth, yield and quality of onion (Allium cepa L.) Journal of Crop and Weed, 11(2):86-89

Nayak B.R., Samanta P.K., Panigrahy N., Mohapatra S., Mohanty A.K., Dash
A.K., Jena B., Panda N., Sahoo B., and Mishra P., 2016.Responce of different sources and doses of sulphur on growth, yield and uptake of onion (Allium cepa). International Journal of Bio-resource and Stress Management. 7(1):066-069

Meher R., Mandal J., Saha D., and Mohanta S., 2016.Effect of sulphur application in onion (Allium cepa).Journal of Crop and Weed,12(3):86-90.

Gondane S.P., Chandan P.M., and Panchal K. N., 2018. Effect of different levels of sulphur on yield and quality of onion. International Journal of Current Microbiology and Applied Sciences, Special issu-6:2125-2132

\section{How to cite this article:}

Bhoite Vivek, M. R. Backiyavathy and Prajakta Metkari-Kharat 2019. Effect of Sources and Graded Levels of Sulphur on Growth and Yield of Bellary Onion (Allium cepa L.). Int.J.Curr.Microbiol.App.Sci. 8(09): 2233-2239. doi: https://doi.org/10.20546/ijcmas.2019.809.257 